\title{
FISKALNI RIZICI PRIRODNIH NEPOGODA U HRVATSKOJ
}

\author{
FISCAL RISKS OF NATURAL DISASTERS IN CROATIA
}

SAŽETAK: Prirodne nepogode specifičan su izvor fiskalnih rizika. Njihovo nastupanje često je povezano s izrazito velikim štetama, a za sanaciju šteta država izdvaja značajna sredstva koja uglavnom nisu planirana i rezervirana u državnom proračunu. Budući da se radi o rizicima čije nastupanje ovisi isključivo o vanjskim čimbenicima, procjena veličine potrebnih sredstava za sanaciju možebitnih šteta je izazov kako za upravljanje fiskalnim rizicima, tako posljedično i za pripremu proračuna. Zbog slabog upravljanja ovim rizicima na razini države, reakcija na prirodne nepogode je često nedostatna ili zakašnjela, zbog čega inicijalni troškovi prouzročeni prirodnim nepogodama dodatno rastu. Prirodne nepogode su stoga sve češće u fokusu upravljanja financijama javnoga sektora. Za većinu zemalja najveći problemi u upravljanju fiskalnim rizicima prirodnih nepogoda su manjak sredstava, slaba koordinacija i loša reakcija, a s takvim problemima se suočava i Hrvatska. Budući da brojčani pokazatelji vezani uz troškove prirodnih nepogoda ukazuju na značajne fiskalne rizike koji proizlaze iz tog izvora, cilj rada je skrenuti pozornost na potrebu razvijanja kvalitetnih instrumenata ublažavanja i prijenosa rizika prirodnih nepogoda u Hrvatskoj. Prirodne nepogode u Hrvatskoj su sve učestalije, a razmjeri štetnih posljedica su sve veći i stvaraju veliko opterećenje za državni proračun kao glavni izvor financiranja troškova prirodnih nepogoda.

KLJUČNE RIJEČI: fiskalni rizici, prirodne nepogode, Hrvatska, strategija upravljanja fiskalnim rizicima.

JEL: H84, H56, H63, Q54.

Doc. dr. sc. Marko Primorac, Ekonomski fakultet - Zagreb, mprimorac@efzg.hr

Lucija Golub, mag. oec., lucijag4@gmail.com

Ovaj rad nastao je temeljem diplomskog rada kojeg je Lucija Golub izradila i obranila pod mentorstvom doc. dr. sc. Marka Primorca. 


\begin{abstract}
Natural disasters are a specific source of fiscal risk. Their occurrence is often associated with extremely large damage. Governments often allocate significant funds for the repair of damage, but those funds are usually not planned and reserved in the state budget. As the emergence of natural disasters depends solely on external factors, estimating the amount of funds needed to repair the possible damage is a challenge both for the fiscal risks management, but also for the budget preparation process. Due to the poor management of these risks at the national level, the response to natural disasters is often insufficient or delayed, causing gradual expansion of the initial costs caused by natural disasters. Natural disasters are therefore increasingly in the focus of public sector financial management. For most countries, the biggest problems in managing fiscal risks of natural disasters are the lack of resources, poor coordination and inadequate response. Croatia is also one of the countries facing these problems. Since numerical indicators related to the costs of natural disasters point to significant fiscal risks stemming from this source, the aim of this paper is to draw attention to the need of developing adequate instruments for the mitigation and transfer of natural disaster risks in Croatia. The occurrence of natural disasters in Croatia is increasing, as well as the magnitude of the adverse effects, creating a heavy burden on the state budget as a major financing source for the costs of natural disasters.
\end{abstract}

Key words: fiscal risks, natural disasters, Croatia, fiscal risk management strategy.

\title{
1. UVOD
}

Fiskalni rizici predstavljaju odstupanja fiskalnih ishoda od onoga što se očekivalo u trenutku izrade proračuna ili odstupanja od drugih predviđanja prouzročena makroekonomskim šokovima i pretvaranjem neizravnih (potencijalnih) obveza u izravne (Lusine, et al., 2009., str. 4.). Promatrajući ih u kontekstu upravljanja financijama u javnom sektoru, prirodne nepogode su poseban izvor fiskalnih rizika za državu i pripadaju skupini tzv. specifičnih fiskalnih rizika (Primorac i Župančić, 2016.). Zbog nepredvidivosti nastupanja prirodnih nepogoda, kao i razmjera štete koju uzrokuju, rizici prirodnih nepogoda predstavljaju jedan od najvećih izazova u okviru upravljanja fiskalnim rizicima, ali i proračunskog planiranja. Prirodne nepogode mogu se svrstati u 4 kategorije: geo-fizičke (potres, tsunami, vulkanska aktivnost, klizišta), meteorološke (cikloni, oluje, uragani, ledene i snježne oluje), hidrološke (poplave, bujice) i klimatološke (ekstremne hladnoće i vrućine, suše, požari itd.) (Munich RE, 2011., str. 4).

Kod upravljanja fiskalnim učincima prirodnih nepogoda najviše pozornosti pridaje se posljedicama prirodnih nepogoda za državu, vlasnike nekretnina, male i srednje poduzetnike, farmere i poljoprivrednike te siromašni dio stanovništva. Učinci su najčešće financijske naravi i utječu na razvoj i stabilnost navedenih skupina (World Bank Group, 2014., str. 15-16). Središnja uloga vlade i države u situaciji nastanka prirodnih nepogoda je pružanje pomoći u oporavku i rekonstrukciji, što podrazumijeva velike izravne financijske izdatke. Makroekonomski troškovi smanjenja rasta BDP-a i kumulativni trajni gubici BDP-a nakon pojave prirodnih nepogoda indirektno utječu na državni proračun, a moguće je i povećanje troškova zaduživanja, posebice za već zadužene države (World Bank Group, 2014., str. 16-18).

Prirodne nepogode u Hrvatskoj su sve učestalije, a razmjeri štetnih posljedica su sve veći i stvaraju veliko opterećenje za državni proračun kao glavni izvor financiranja troškova 
prirodnih nepogoda. Cilj ovoga rada je analizirati učinke prirodnih nepogoda, štete i troškove koje stvaraju te mogućnosti apsorpcije tih troškova. Ova tema u hrvatskoj znanstvenoj literaturi dosad nije detaljnije obrađivana, zbog čega je nužno skrenuti pozornost na dostupne informacije i podatke koji se mogu koristiti za daljnje analize i razvijanje strategije upravljanja fiskalnim rizicima prirodnih nepogoda u Hrvatskoj.

Nakon uvodnog dijela, u drugom dijelu se opisuju strategije upravljanja rizikom prirodnih nepogoda, analiziraju troškovi relevantnih prirodnih nepogoda te navode ex ante i ex post metode financiranja tih troškova. Treći dio je posvećen fiskalnim učincima prirodnih nepogoda u Hrvatskoj, njihovoj učestalosti, prijavljenim i potvrđenim štetama kao i načinima financiranja troškova sanacije tih šteta. U četvrtom dijelu se navode mogućnosti unaprjeđenja upravljanja fiskalnim rizicima prirodnih nepogoda kroz analizu mogućih postupaka za ublažavanje posljedica te opisivanje tradicionalnih i suvremenih metoda i instrumenata za prijenos rizika. Peti dio rada je zaključak.

\section{STRATEGIJE UPRAVLJANJA RIZIKOM PRIRODNIH NEPOGODA}

Upravljanje rizicima prirodnih nepogoda (engl. Disaster Risk Management - DRM) podrazumijeva sustavni proces korištenja administrativnih uputa, organizacije, operativnih vještina i kapaciteta u cilju provođenja strategija, politika i poboljšanja raspoloživih kapaciteta za smanjenje negativnih posljedica prirodnih nepogoda (International standard ISO 3100, 2009.).

Procjena rizika i obrada rizika, koja podrazumijeva financiranje i prijenos rizika, ključne su aktivnosti u okviru upravljanja rizicima prirodnih nepogoda i utvrđivanja njihovih fiskalnih učinaka (OECD, 2012., str. 9-10). Nakon što je rizik poznat, identificiran, analiziran i kvantificiran, slijedi uspostava mehanizama i planova za proaktivno upravljanje očekivanim fiskalnim učincima. Financiranje rizika uključuje donošenje strategije financiranja kako bi se osigurala dostatna sredstva za zadovoljenje financijskih potreba u slučaju prirodnih nepogoda. Prijenos rizika označava prebacivanje rizika drugim subjektima koji, u zamjenu za premiju, pružaju naknadu ako dođe do nastupanja rizika - pojave prirodne nepogode (OECD, 2012., str. 57).

Štete koje nastaju kao posljedica prirodnih nepogoda mogu značajno utjecati na proračun, ali i ukupno ekonomsko i gospodarsko stanje zemlje i društva. Globalni gubici uslijed registriranih relevantnih prirodnih nepogoda u razdoblju od 2000. do 2018. (grafikon 1.) iznose u prosjeku 162 mlrd. američkih dolara godišnje. U posljednje tri godine broj relevantnih događaja izazvanih prirodnim nepogodama kreće se iznad 700, a iznos gubitaka od 178,0 do čak 345,0 mlrd. dolara. 


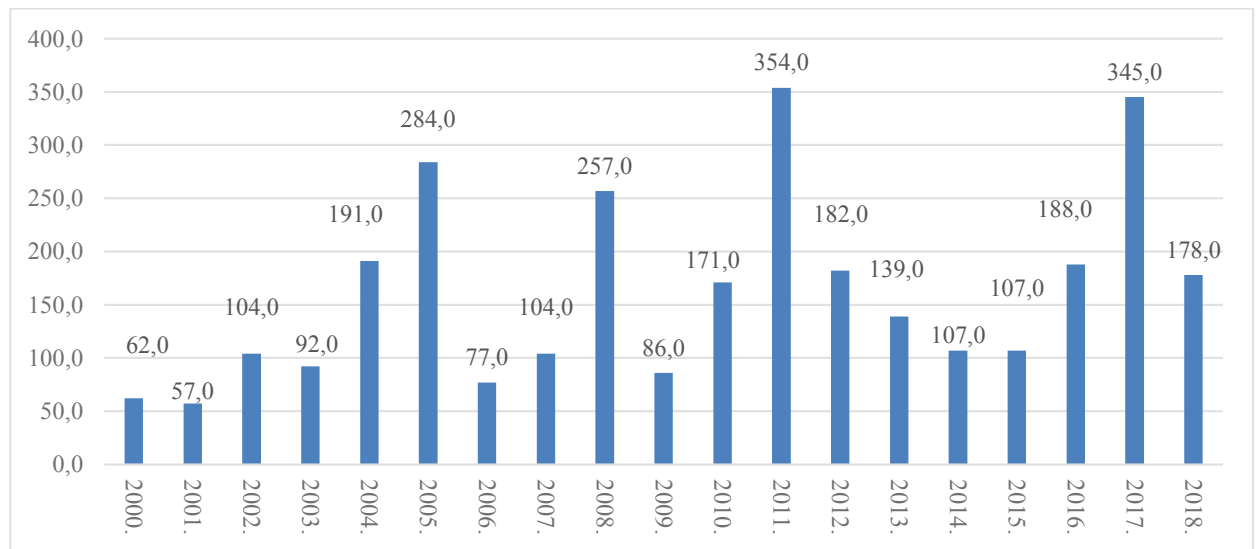

Grafikon 1. Gubici od prirodnih nepogoda u svijetu od 2000. do 2018. (u mlrd. dolara)

Izvor: izrada autora prema podacima NatCatService, 2019. Dostupno na: http://natcatservice.munichre.com/overall/1?filter=eyJ5ZWFyRnJvbSI6MjAwMCwieWVhclRvIjoyMDE3fQ\%3D\%3D\&type=1.

Broj prirodnih nepogoda u svijetu raste, a najveći rast bilježe hidrološki i meteorološki događaji koji su i najučestaliji (grafikon 2.). Poplave su opasnost koja prijeti najviše zemalja diljem svijeta, a vrlo su učestale u zemljama EU-a koje obiluju bogatstvom rijeka i mora. Osim poplava, vrlo su česte i ekstremne niske ili visoke temperature te oluje, uragani ili cikloni. Požari su također sve češći u velikom broju zemalja. Najviše prijete šumama, a mogu rezultirati i velikim materijalnim štetama za kućanstva i cijelu infrastrukturu. Značajne štete uzrokuju i potresi koji mogu potaknuti razvoj drugih nepogoda kao što su klizišta, tsunami i lavine (Directorate-General for European Civil Protection and Humanitarian Aid Operations, 2017., str. 17-29).

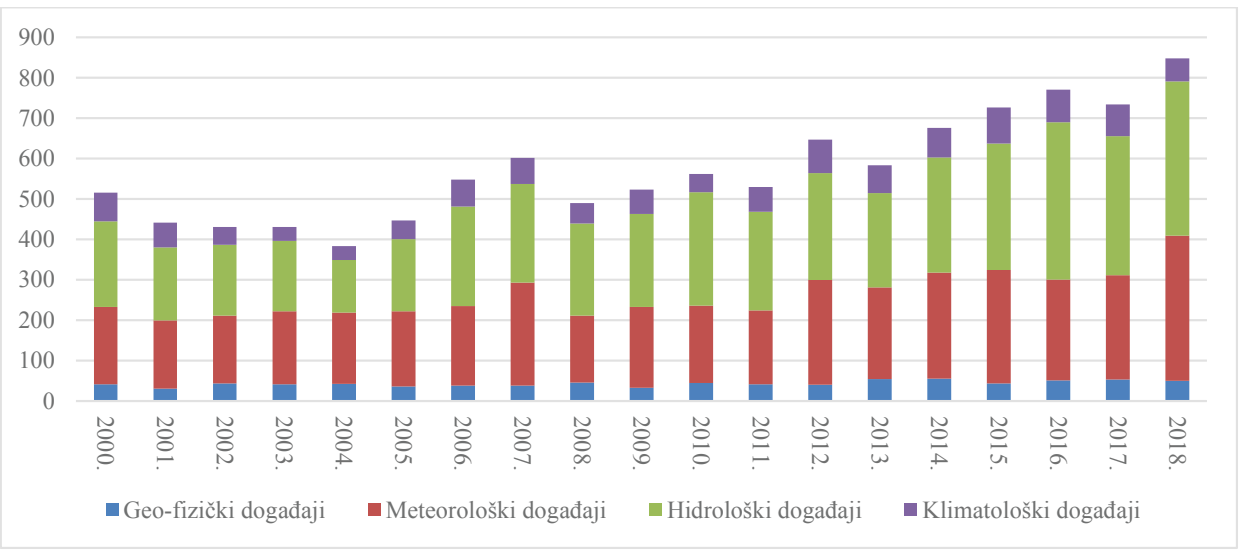

Grafikon 2. Broj relevantnih prirodnih nepogoda u svijetu od 2000. do 2018. godine

Izvor: izrada autora prema podacima NatCatService, 2019. Dostupno na: http://natcatservice.munichre.com/overall/1?filter=eyJ5ZWFyRnJvbSI6MjAwMCwieWVhclRvIjoyMDE3fQ\%3D\%3D\&type=1. 
Ekonomski učinci prirodnih nepogoda mogu se ublažiti prije (ex ante) i nakon nastupa prirodnih nepogoda (ex post). Za razliku od ex ante metoda koje zahtijevaju proaktivnost i planiranje unaprijed, ex post metode uglavnom su reaktivnog karaktera.

Ex ante metoda podrazumijeva primjenu proaktivnih alata za financijsko upravljanje i prijenos rizika te kompenzacijskih aranžmana koje pruža privatni sektor ili država kao dodatak mjerama fizičkog smanjenja rizika (OECD, 2012., str. 49-50). Prema (Skees, 2009., str. 18-19), prednosti ex ante metoda financiranja rizika uključuju prijenos financijskog rizika koji omogućuje pristup globalnim tržištima kapitala koji mogu apsorbirati financijsku izloženost štetnim događajima; bolje planiranje i otpornost na ekonomske i gospodarske učinke; brži odgovor na nastup prirodnih nepogoda i hitne situacije; strukturirana pravila i smanjenje korupcije; bolje raspoređivanje ograničenih resursa; ublažavanje financijskih učinaka za javni i privatni sektor te olakšano planiranje i osmišljavanje strategija za upravljanje fiskalnim rizicima.

Ex post metode financiranja i prijenosa rizika prirodnih nepogoda fokusiraju se uglavnom na ublažavanje posljedica i oporavak nakon nastupa nepovoljnog događaja. Cilj je odrediti programe hitne pomoći, uključujući i pomoć za obnovu, utvrditi točne iznose i vrste pomoći (Kirschner i Phaup, 2009., str. 11-13).

Tablica 1. Primjeri metoda za financiranje i prijenos rizika

\begin{tabular}{|c|c|}
\hline Ex ante & Ex post \\
\hline Fond rezervi & Rebalans proračuna \\
\hline Potencijalne kreditne linije & Domaće i međunarodno zaduživanje \\
\hline Osiguranje & Povećanje poreza \\
\hline Obveznice za katastrofe & Međunarodna pomoć donatora \\
\hline
\end{tabular}

Izvor: sistematizacija autora.

Ex ante i ex post metode u praktičnoj primjeni poprimaju različite pojavne oblike. Tako se uz Ex ante metode najčešće vežu fondovi rezervi, potencijalne kreditne linije, osiguranje i obveznice za katastrofe, dok ex post metode najčešće obuhvaćaju rebalans proračuna, domaće i međunarodno zaduživanje, povećanje poreza te međunarodnu pomoć donatora. U nastavku je kratak pregled najčešće korištenih metoda.

Fond rezervi podrazumijeva namjenska sredstva štednje ili rezervi odnosno izvor financiranja interno generiranim sredstvima koja se izdvajaju u fondu i povlače u slučaju prirodne nepogode. Prednost fonda rezervi je pravodobna dostupnost financijskih sredstava i smanjenje ovisnosti o financiranju dugom. Meksiko, primjerice, za upravljanje troškovima prirodnih nepogoda koristi fond za prirodne nepogode FONDEN, a on se sastoji od dva dopunska proračuna - za obnovu i za prevenciju. Sredstva u fondu prikupljaju se iz saveznog proračuna, a iznos izdvojenih sredstava ne smije biti manji od 0,4 \% godišnjeg proračuna. Osim toga, Meksiko reosiguranjem i obveznicama za katastrofe povećava financijsku sposobnost (otpornost) i smanjuje izloženost države rizicima prirodnih nepogoda (The World Bank, 2012., str. 1-6). 
Potencijalne kreditne linije odnose se na pristup vanjskim izvorima financiranja koji pružaju kredite i zajmove u slučaju prirodne nepogode. Sredstva su odmah spremna za isplatu, a interna sredstva se mogu koristiti u druge svrhe. Potencijalni kredit je vrsta financijskog instrumenta koja državama osigurava sredstva prije nastanka prirodne nepogode. Inter-američka banka za razvoj (eng. Inter-American Development Bank - IDB) pokrenula je kreditnu liniju za prirodne nepogode 2012., a Japanska agencija za međunarodnu suradnju (engl. Japan International Cooperation agency - JICA) je 2013. uspostavila kreditnu liniju za pokriće hitnih financijskih potreba nakon prirodnih nepogoda u iznosu do $0,25 \%$ BDP-a (Financial Protection Forum, 2017., str. 1).

Osiguranje omogućava prijenos rizika na poduzetnike odnosno osiguravatelje i reosiguravatelje. U zemljama gdje su tržišta osiguranja razvijena, osiguranje pruža jednostavnu i ekonomičnu financijsku zaštitu bez potrebe akumuliranja vlastitih sredstava kao u slučaju fonda rezervi. Osiguranjem od prirodnih nepogoda osiguranici plaćaju premiju kako bi im osiguratelj nadoknadio dio nastalih troškova nakon prirodne nepogode. Ograničenje osiguranja je u tome što sredstva nisu odmah dostupna, a nedostatak su i oportunitetni troškovi tekućih premija osiguranja koje se ne akumuliraju u slučaju izostanka nepogoda, već predstavljaju rashod neovisno o tome je li došlo do prirodne nepogode ili nije (United Nations Development Programme, 2017.).

Zaštita od rizika prirodnih nepogoda kroz obveznice za katastrofe (engl. catastrophe bonds ili „cat bonds“) djeluje tako da investitori kupuju državnu obveznicu i pohranjuju je u subjekt posebne namjene (engl. Special Purpose Vehicle - SPV). Investitori prikupljaju kamate na obveznicu i premije osiguranja koje plaća država te pripadajuću glavnicu po isteku roka dospijeća. Ako se u utvrđenom roku dogodi prirodna nepogoda, investitor ne dobiva glavnicu, već samo dotad dospjeli prinos. Subjekt posebne namjene prodaje obveznicu i prenosi sredstva osiguranoj strani - državnom proračunu (Cavallo i Noy, 2010., str. 23). Jedno od najvećih izdanja na tržištu obveznica za katastrofe je ono Svjetske banke 2018. u iznosu od 1,36 mlrd. dolara za zaštitu od potresa u Čileu, Kolumbiji, Meksiku i Peruu (The World Bank, 2018.).

Rebalans proračuna jedna je od ex post metoda financiranja rizika, a koristi se u zemljama koje su iznimno rijetko pogođene prirodnim nepogodama ili zemljama koje nemaju razvijen sustav financijskog upravljanja i upravljanja fiskalnim rizicima. Budući da su proračunska sredstva ograničena, a troškovi prirodnih nepogoda mogu biti značajni, u manjim državama je gotovo nemoguće rebalansom proračuna iznaći financijska sredstva kojima bi se mogli pokriti troškovi prirodnih nepogoda - osobito ako nastupe krajem godine kada je proračun već iscrpljen. Učestala primjena rebalansa ugrožava razvojne programe koji zahtijevaju dugo razdoblje pripreme (Ghesquiere i Mahul 2010., str. 8-9). Srbija je primjer zemlje koja koristiti rebalans za preraspodjelu sredstava kako bi pomogla lokalnim vlastima i javnim poduzećima u fazi obnove nakon prirodne nepogode. Iako formalno postoji proračunska pričuva kao mjera ex ante financiranja, ona u Srbiji ima simboličko značenje jer su sredstva koja se izdvajaju u proračunskoj pričuvi toliko skromna da ne mogu pokriti ni najosnovnije troškove sanacije. U slučaju prirodnih nepogoda proračunska pričuva se povećava rebalansom. Primjerice, u 2014. su povećana sredstva za sanaciju sa 17 tis. eura na približno 20 mil. eura, ali je zbog administrativnih procedura novac osiguran tek nakon 5 mjeseci (Signer, et al., 2016., str. 17). 
Zaduživanje može zahtijevati dugo pregovaranje i ne pruža primjerenu mobilizaciju resursa za sanaciju štete nastale prirodnim nepogodama. Ono može pružiti dodatne financijske kapacitete, ali je ograničeno mogućnošću zaduživanja pojedine države, što je otegotna okolnost za manje zemlje koje već imaju visok dug (Ghesquiere i Mahul 2010., str. 9-11). Bangladeš je, primjerice, jedna od zemalja koja bilježi sve veći omjer javnog duga (uglavnom domaćeg) prema BDP-u, a jedan od razloga tome je i zaduživanje za potrebe izvanrednih situacija kao što su prirodne nepogode (Mahmood, 2017.). Zaduživanje se, osim na domaćem, može obaviti i na međunarodnom tržištu. Australija je primjer zemlje koja financira troškove nastale prirodnim nepogodama u okviru Aranžmana za olakšanje i oporavak od prirodnih nepogoda te se zadužuje na međunarodnom tržištu. Dobar financijski položaj i kreditni rejting omogućava joj pristup financijskim tržištima u inozemstvu i zaduživanje po povoljnim uvjetima (OECD, str. 62).

Nakon prirodne nepogode vlade pogođenih zemalja obično povećavaju poreze kako bi prikupile dodatna financijska sredstva za financiranje obnove pogođenih područja. Povećanje poreznog tereta je uglavnom privremeno, a u praksi se najčešće povećava porez na dodanu vrijednost, porez na dohodak ili specifični porezi na potrošnju (porez na određene proizvode poput cigareta, alkoholnih pića i goriva). Ekvador je 2016. bio pogođen razornim potresom koji je izazvao velike štete i proglašenje prirodne katastrofe. Vlada je za potrebe saniranja štete i financiranja troškova povećala porez na dodanu vrijednost za $2 \%$, porez na dobit za $3 \%$ te uvela dodatan jednokratni porez osobama s imovinom vrijednom milijun dolara i više (Martinez i Ore, 2016.).

Međunarodna pomoć donatora odnosi se na resurse koje pružaju službene agencije s namjerom promocije gospodarskog razvoja. Pomoć se pruža za rekonstrukciju ili prevenciju šteta uzrokovanih prirodnim nepogodama, a najčešće je usmjerena na određene sektore (Apodaca, 2017., str. 4). Međunarodna pomoć dolazi od velikog broja donatora od kojih su najveći Svjetska banka i Japan. U razdoblju od 1991. do 2010. ukupna međunarodna pomoć iznosila je 3,03 bil. američkih dolara od čega je 106,7 mlrd. bilo za prirodne nepogode. Jedan od većih izdataka zabilježen je 2010. kada je zbog razornog potresa 1,8 mlrd. dolara pomoći dodijeljeno Haitiju koji je pretrpio oko 7,8 mlrd. dolara štete (Caravani i Kellett, 2013., str. 5-10).

\section{FISKALNI UČINCI PRIRODNIH NEPOGODA U REPUBLICI HRVATSKOJ}

Prirodne nepogode značajno utječu na društveni i ekonomski razvoj. One narušavaju normalno odvijanje života, uzrokuju žrtve, štetu na imovini i infrastrukturi. Štetne posljedice prirodnih nepogoda mogu se ublažiti kvalitetnim preventivnim strategijama (Ivančan-Picek, 2015.).

Budući da je država zadužena za zaštitu vitalnih nacionalnih interesa ona je ujedno najodgovornija za stvaranje i financiranje kapaciteta kojima će te interese učinkovito zaštititi. Hrvatska ima geografska i klimatska obilježja koja ju izlažu riziku nastanka prirodnih nepogoda. Unatoč tome, središnja država i lokalne jedinice često nemaju primjerene resurse za učinkovito financiranje i zaštitu od rizika prirodnih nepogoda (Državna uprava za zaštitu i spašavanje [DUZS], 2015., str. 416). 
Najučestalija prirodna nepogoda u Hrvatskoj su poplave, ali vrlo su česti i temperaturni ekstremi i požari. Slijede suše, uragani i potresi (grafikon 3.).

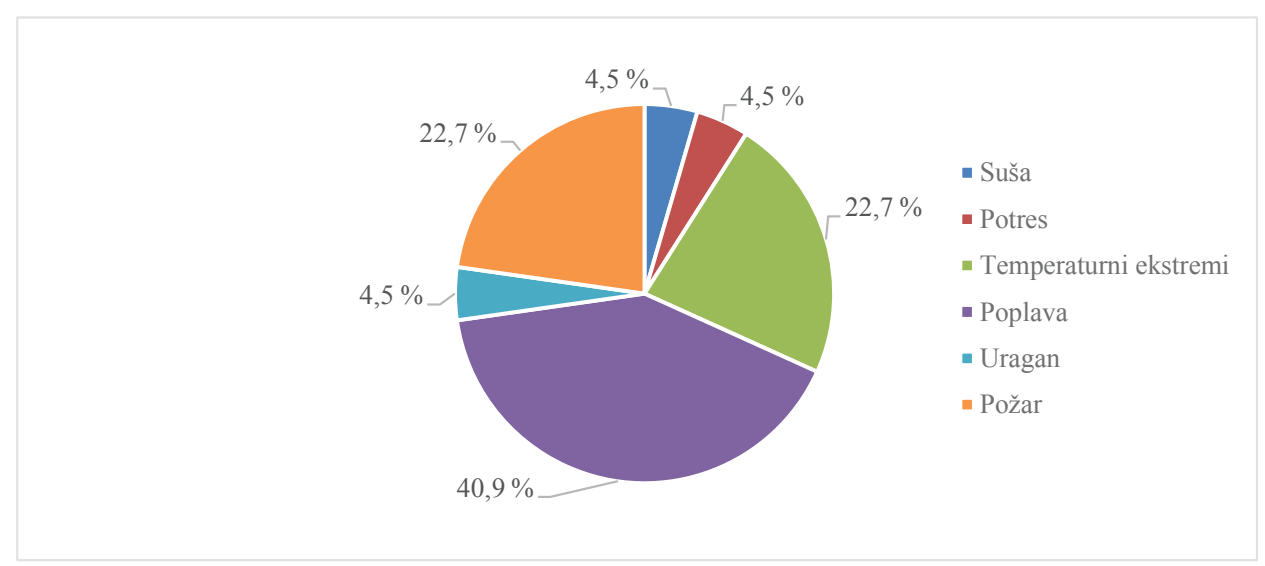

Grafikon 3. Učestalost prirodnih nepogoda u RH od 1990. do 2014.

Izvor: EM-DAT The International disasters database, 2015. Dostupno na: https://www.preventionweb.net/countries/hrv/data/.

Nacionalnom procjenom rizika utvrđeno je da su poplave, potresi i požari najvjerojatniji štetni događaji s najgorim posljedicama zbog čega je potrebno smanjiti izloženost takvim rizicima u najkraćem mogućem roku (DUZS, 2015., str. 442).

Gotovo četvrtina hrvatskog gospodarstva temelji se na sektorima koji su najizloženiji klimatskim promjenama i prirodnim nepogodama, a to uključuje poljoprivredu, turizam i energetski sektor. Štete kojima su ti sektori izloženi su značajne, a kapaciteti države nisu dovoljni za naknadu šteta i prevenciju. Prvi korak prema smanjenju rizika prirodnih nepogoda je procjena ugroženosti i identifikacija najbitnijih rizika. To se Nacionalnom procjenom uspješno obavilo, no potrebna je daljnja koordinacija i suradnja svih nadležnih tijela kako bi se stvorili kvalitetni mehanizmi ublažavanja negativnih posljedica prirodnih nepogoda.

Područje prirodnih nepogoda i povezanih rizika, kao i sanacije šteta uzrokovanih prirodnim nepogodama, je do 2019. bilo uređeno Zakonom o zaštiti od elementarnih nepogoda (NN 73/97., 174/04.), a od 2019. je uređeno Zakonom o ublažavanju i uklanjanju posljedica prirodnih nepogoda (NN 16/19.). Osim toga, objavljen je Pravilnik o Registru šteta od prirodnih nepogoda (NN 65/19.), a stupanjem na snagu navedenog Pravilnika, prestaju važiti odredbe propisane Metodologijom za procjenu štete od elementarnih nepogoda (NN 96/98.).

Pružanje pomoći nakon prirodne nepogode ostvaruje se na lokalnoj i područnoj (regionalnoj) razini, na razini središnje države te kod društava za osiguranje ako su štete osigurane. Pravo na pomoć iz državnog proračuna imaju fizičke osobe, iznimno i pravne, u jedinicama lokalne samouprave, a prirodna nepogoda može se proglasiti ako je vrijednost ukupne izravne štete najmanje $20 \%$ vrijednosti izvornih prihoda jedinice lokalne samouprave za prethodnu godinu, ako je prirod (rod) umanjen za najmanje $30 \%$ prethodnog trogodišnjeg prosjeka na području jedinice lokalne samouprave ili ako je nepogoda umanjila 
vrijednost imovine na području jedinice lokalne samouprave za najmanje $30 \%$ (Zakon o ublažavanju i uklanjanju posljedica prirodnih nepogoda, NN 16/19.). Praćenje i analiza podataka o prirodnim nepogodama u Hrvatskoj bilježi se putem Registra šteta ustrojenog 2014. Podaci koji se bilježe su vrsta šteta, vrijeme nastanka nepogode, vrsta korisnika i područje zahvaćeno nepogodom. Na službenim stranicama Ministarstva financija javno su objavljeni podaci o prijavljenim štetama po vrsti i vremenu nastanka od 2013. do 2018.

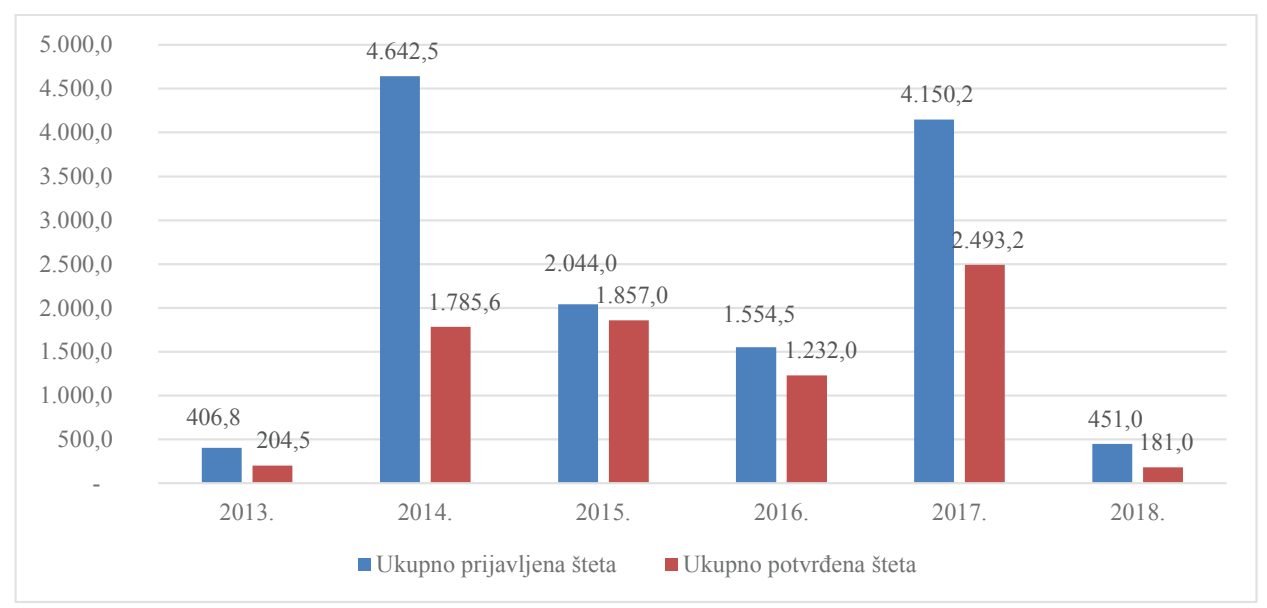

Grafikon 4. Prijavljena i potvrđena šteta od 2013. do 2018. (u mil. kuna)

Izvor: izrada autora prema podacima Ministarstva financija.

Prijavljena šteta se kreće od nešto manje od 0,5 mil. kuna do čak preko 4,5 mlrd. kuna. U 2013. su najviše štete prouzročila klizišta i odroni, tuče i poplave, a u 2014. ledena kiša koja je zahvatila Primorsko-goransku županiju i poplave koje su pogodile cijelu istočnu Hrvatsku. Najveću štetu u 2015. prouzročila je suša, u 2016. i 2017. mraz, a u 2018. požari. Ukupno potvrđena šteta od prirodnih nepogoda kreće se od 38 \% prijavljene štete u 2014. do $91 \%$ prijavljene štete u 2015.

Grafikon 5. Udio prijavljene štete od prirodnih nepogoda po sektorima za razdoblje od 2013. do 2018.

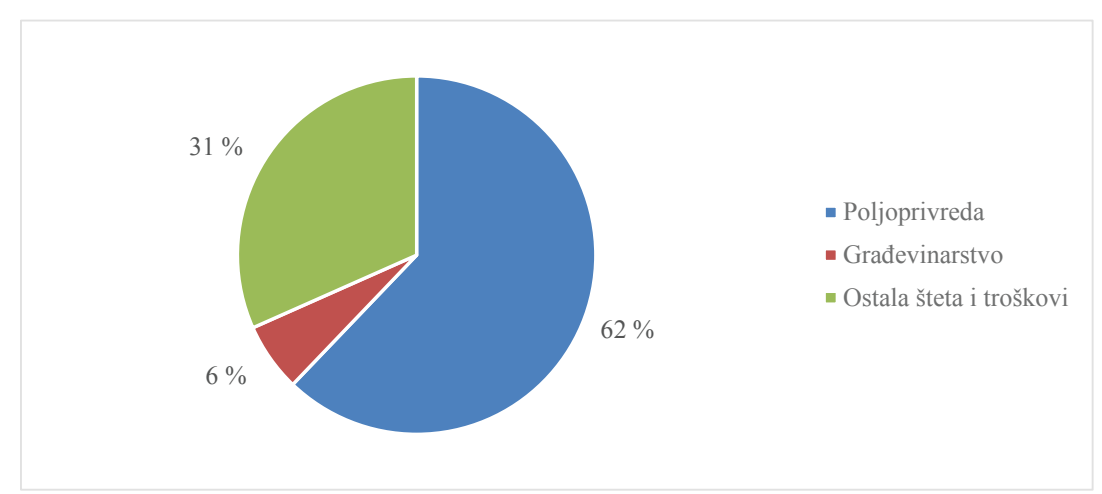

Izvor: izrada autora prema podacima Ministarstva financija. 
Najveći udio prijavljene štete u razdoblju od 2013. do 2018. (62\%) odnosi se na poljoprivredu, upola manji udio ima građevinarstvo (31 \%) (šteta na stambenim objektima i poslovnim prostorima), a vrlo mali udio (6\%) odnosi se na štetu na opremi i infrastrukturi.

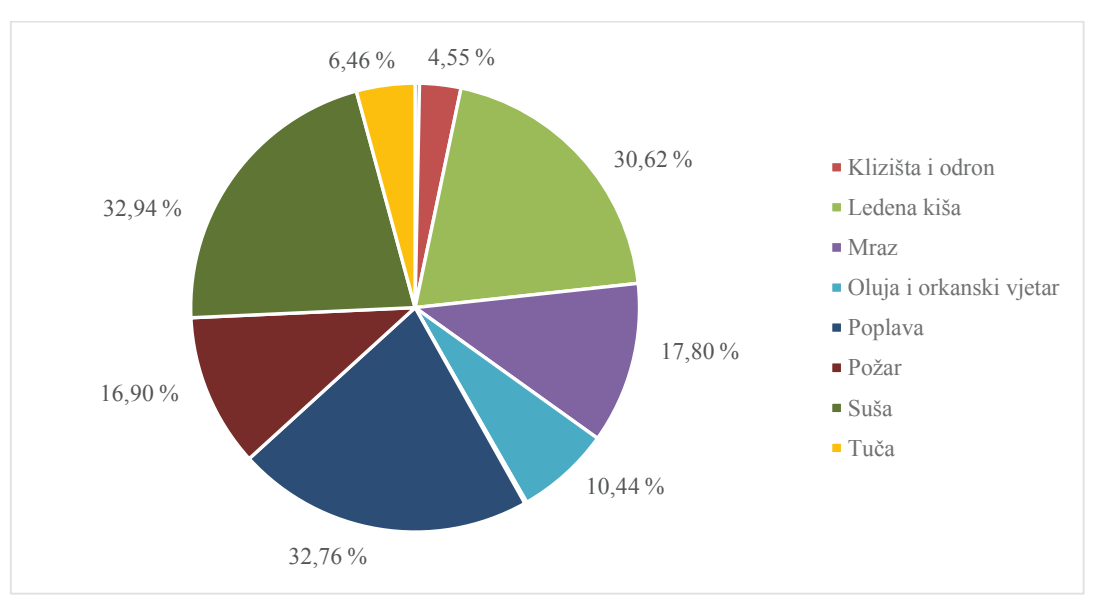

Grafikon 6. Udio vrste prirodne nepogode u ukupnoj prijavljenoj šteti od 2013. do 2018.

Izvor: izrada autora prema podacima Ministarstva financija.

Najčešće štete su od suše, poplava, ledene kiše i mraza. Prema analizi učestalosti nastanka prirodnih nepogoda temperaturni ekstremi, poplave i požari najučestaliji su u razdoblju do 2014., a takav trend je prisutan i u novije vrijeme.

Prema izvješću Europske agencije za okoliš (engl. European Environment Agency $E E A$ ), države članice Europskog gospodarskog prostora (engl. European Economic Area - EEA) su u razdoblju od 1980. do 2017. zabilježile gubitke od prirodnih nepogoda u iznosu od 453 mlrd. eura (u prosjeku 12 mlrd. eura godišnje). Kumulativni gubici u tom razdoblju čine gotovo 3 \% BDP-a svih zemalja članica Europskog gospodarskog prostora, a najveći udio ukupnih gubitaka u kumulativnom BDP-u registriran je u Hrvatskoj, Češkoj i Mađarskoj (European Environment Agency, 2019.).

Tablica 2. Prijavljene štete od prirodnih nepogoda u RH od 2013. do 2018.

\begin{tabular}{|c|c|c|c|}
\hline Godina & Prijavljena šteta (u mil. kuna) & BDP (u mil. kuna) & Prijavljena šteta (\% BDP-a) \\
\hline 2013. & 406,8 & $331.784,9$ & 0,12 \\
\hline 2014. & $4.642,5$ & $331.569,6$ & 1,40 \\
\hline 2015. & $2.044,0$ & $339.616,2$ & 0,60 \\
\hline 2016. & $1.554,5$ & $351.349,1$ & 0,44 \\
\hline 2017. & $4.150,2$ & $365.643,1$ & 1,14 \\
\hline 2018. & 451,0 & $381.799,0$ & 0,12 \\
\hline
\end{tabular}

Izvor: izrada autora prema podacima Ministarstva financija i HNB-a. 
Prijavljena šteta od prirodnih nepogoda u Hrvatskoj iznosi između 0,12 \% BDP-a 2013. i 2018. i 1,40 \% BDP-a 2014. Najveće štete od prirodnih nepogoda prijavljene su 2014. i 2017., a u tim godinama dolazi i do smanjenja BDP-a na godišnjoj razini. Ne može se sa sigurnošću konstatirati da je taj pad prouzročen prirodnim nepogodama no njihov učinak na kretanje BDP-a je zasigurno bio negativan.

Prema podacima NatCatService platforme mogu se analizirati i evidentirani relevantni gubitci od prirodnih nepogoda po zemljama. Platformom su obuhvaćeni podaci za prirodne nepogode koje su prouzročile najmanje jedan gubitak ljudskog života i/ili stvorile normalizirane gubitke veće ili jednake 100 tisuća, 300 tisuća, 1 milijun ili 3 milijuna američkih dolara, ovisno o dohodovnoj skupini pogođene zemlje.

Tablica 3. Gubici od prirodnih nepogoda u RH od 2000. do 2018. ( u USD)

\begin{tabular}{|c|r|c|r|}
\hline Godina & Iznos gubitaka & Godina & Iznos gubitaka \\
\hline 2000. & 89.000 .000 & 2010. & 170.000 .000 \\
\hline 2001. & - & 2011. & - \\
\hline 2002. & 300.000 & 2012. & 170.000 .000 \\
\hline 2003. & 690.000 .000 & 2013. & - \\
\hline 2004. & 100.000 & 2014. & 610.000 .000 \\
\hline 2005. & 1.100 .000 & 2015. & 82.000 .000 \\
\hline 2006. & 5.300 .000 & 2016. & - \\
\hline 2007. & 1.400 .000 & 2017. & 250.000 .000 \\
\hline 2008. i 2009. & - & 2018. & 3.000 .000 \\
\hline
\end{tabular}

Izvor: izrada autora prema podacima NatCatService.

Iznos gubitaka varira iz godine u godinu, a ističu se 2003. koju je obilježilo iznimno dugačko razdoblje suše i 2014. koja će ostati zapamćena po poplavama ekstremnih razmjera. Iako za neke od promatranih godina nisu dostupni podaci, može se utvrditi kako je prosječan relevantni gubitak od prirodnih nepogoda u Hrvatskoj od 2000. do 2018., zabilježen putem NatCatService platforme, nešto viši od 159 mil. dolara odnosno 1,1 mlrd. kuna, godišnje.

Hrvatska je u posljednje vrijeme ostvarila znatan napredak u području planiranja izdataka, što se pozitivno odražava i na planiranje sredstava za naknadu šteta od prirodnih nepogoda. Registar šteta Ministarstva financija prikazuje iznose prijavljenih šteta, ali ne i ekonomske učinke prirodnih nepogoda na cjelokupno gospodarstvo. Udio potrebnih financijskih sredstava za sanaciju šteta u BDP-u je prevelik te iziskuje veći broj izvora sredstava kako bi se podijelio teret financiranja.

Prema Zakonu o ublažavanju i uklanjanju posljedica prirodnih nepogoda, novčana sredstva i druge vrste pomoći za djelomičnu sanaciju šteta od prirodnih nepogoda na imovini oštećenika osiguravaju iz državnog proračuna s proračunskog razdjela ministarstva nadležnog za financije, fondova Europske unije te donacija (NN 16/19.).

Najveće fiskalno opterećenje za reagiranje u slučaju prirodnih nepogoda i financijsku potporu preuzima središnja država koja sredstva osigurava izravno iz državnog proračuna 
ili kroz proračune pojedinih središnjih tijela državne uprave. Glavni korisnici tih sredstava su Državna uprava za zaštitu i spašavanje (DUZS)2 , vatrogastvo, Hrvatska gorska služba spašavanja (HGSS) i Hrvatski crveni križ (DUZS, 2015., str. 418).

Sukladno novom Zakonu o ublažavanju i uklanjanju posljedica prirodnih nepogoda državno povjerenstvo radi osiguranja novčanih sredstava za potrebe djelomične sanacije šteta nastalih zbog prirodnih nepogoda mora donijeti plan iznosa sredstava te ga uz obrazloženje dostaviti ministarstvu nadležnom za financije, u skladu s pravilima proračunskog planiranja i propisa kojima se uređuju javne financije. Planiranje sredstava posebno uključuje analize vjerojatnosti nastanka prirodne nepogode, uzima u obzir razmjere nastale štete i razvijenost pojedinih područja u kojima nastaje prirodna nepogoda (najmanje za proteklih pet godina prema indeksu razvijenosti), pri čemu se koristi podacima nadležnih institucija i Procjenom rizika od katastrofa za Republiku Hrvatsku u određenjima procjene i vjerojatnosti mogućnosti nastanka šteta od prirodnih nepogoda u sljedećem razdoblju (NN 16/19.).

Vlada RH može odlučiti o davanju sredstava žurne pomoći iz državnog proračuna ili iz njegove tekuće pričuve (NN 73/97; NN 16/19.). Tekuća pričuva ili proračunska zaliha je poseban dio sredstava proračuna namijenjen za nepredviđene namjene za koje u proračunu nisu osigurana sredstva ili nisu utvrđena dovoljna sredstva. Dakle, njihova namjena je i financiranje rashoda nastalih pri otklanjanju posljedica prirodnih nepogoda i drugih nepredvidivih nesreća. Takva sredstva mogu iznositi najviše $0,5 \%$ planiranih proračunskih prihoda bez primitaka, a utvrđuju se odlukom o izvršavanju proračuna (NN 15/15.).

Unutar državnog proračuna, prema programskoj klasifikaciji, stavka A539025 predstavlja aktivnost koja se naziva 'Naknada za štete uzrokovane elementarnim nepogodama'. Godišnje izvješće o izvršenju državnog proračuna pokazuje iznose sredstava koji su isplaćeni za navedenu aktivnost. Vlada RH je dužna objaviti odluku o dodjeli sredstava žurne pomoći i raspodjelu prema oštećenim jedinicama lokalne samouprave.

Tablica 4. Iznos dodijeljene pomoći za potvrđene štete od 2013. do 2018. (u mil. kuna)

\begin{tabular}{|c|c|r|r|r|r|r|r|r|}
\hline \multirow{2}{*}{ Godina } & \multirow{2}{*}{$\begin{array}{c}\text { Potvrđena } \\
\text { šteta }\end{array}$} & \multicolumn{6}{|c|}{ Iznos dodijeljene pomoći za sanaciju štete u kunama } \\
\cline { 3 - 9 } & 2013. & 2014 & 2015. & 2016. & 2017. & 2018. & Ukupno \\
\hline 2013. & 204,5 & 19,8 & 0,4 & - & - & - & - & 20,2 \\
\hline 2014. & $1.785,6$ & - & 35,2 & 19,4 & - & - & - & 54,6 \\
\hline 2015. & $1.857,0$ & - & - & - & - & - & - & - \\
\hline 2016. & $1.232,0$ & - & - & - & 20,0 & - & - & 20,0 \\
\hline 2017. & $2.493,2$ & - & - & - & - & 99,5 & - & 99,5 \\
\hline 2018. & 181,0 & - & - & - & - & - & 20,0 & 20,0 \\
\hline Ukupno & & 19,8 & 35,6 & 19,4 & 20,0 & 99,5 & 20,0 & \\
\hline
\end{tabular}

Izvor: izrada autora prema podacima Ministarstva financija i Vlade RH.

Dakle, za potvrđenu štetu nastalu u 2013. u iznosu od 204,5 mil. kuna iz državnog proračuna je u istoj toj godini isplaćeno 19,8, a u 2014. još 0,4 mil. kuna (ukupno 20,2 mil.

Državna uprava za zaštitu i spašavanje (DUZS) ugašena je 31. 12. 2018., a poslove DUZS-a preuzelo je Ravnateljstvo civilne zaštite uspostavljeno u Ministarstvu unutarnjih poslova (MUP-u). 
kuna). Prema planu proračuna za 2013., za aktivnost 'Naknade za štete od elementarnih nepogoda', bilo je izdvojeno 20 mil. kuna zbog čega je iznos iznad 20 mil. kuna isplaćen u sljedećoj godini. Ministarstvo financija u godišnjem izvještaju o izvršenju državnog proračuna unutar programske klasifikacije iskazuje izvorni plan, tekući plan i izvršenje pojedinih stavki i aktivnosti proračuna.

Aktivnost A539025 - Naknada za štete uzrokovane elementarnim nepogodama je također iskazana u izvještaju, a osim nje postoji i aktivnost A539020 - Procjena šteta od elementarnih nepogoda. Zbroj te dvije aktivnosti prikazuje program 4303 - Otklanjanje posljedica elementarnih nepogoda, a ako mu se dodaju i izdatci iz aktivnosti A539019 Proračunska zaliha, koji se odnose na sanaciju šteta od nepogoda, dobiva se okvirni iznos koji se iz državnog proračuna isplaćuje u slučaju prirodne nepogode. Kroz promatrano razdoblje taj iznos se kreće od 19,3 mil. kuna do 107,1 mil. kuna. Treba napomenuti kako je 2015. iz proračunske zalihe isplaćeno 9,7 mil. kuna Državnom uredu za obnovu i stambeno zbrinjavanje za sanaciju šteta od poplave i 490 tis. kuna Hrvatskoj gorskoj službi spašavanja za obnavljanje neophodne opreme oštećene tijekom sanacije šteta od poplava i zimskog nevremena 2014. U 2017. je iz proračunske zalihe isplaćeno 7,6 mil. kuna Hrvatskoj vatrogasnoj zajednici za uspješnu provedbu zadaća u protupožarnoj sezoni. U situacijama prirodne nepogode ne isplaćuju se sredstva samo za sanaciju štete, već i za funkcioniranje sustava civilne zaštite odnosno obavljenu procjenu šteta te za obavljanje zadaća nadležnih institucija i odjela.

Tablica 5. Izdatci države vezani uz prirodne nepogode od 2013. do 2018. (u tis. kuna)

\begin{tabular}{|l|c|c|c|c|c|}
\hline Godina & $\begin{array}{c}\text { Naknada za } \\
\text { šte EN* } \\
(1)\end{array}$ & $\begin{array}{c}\text { Procjena šteta } \\
\text { od EN* } \\
(2)\end{array}$ & $\begin{array}{c}\text { Otklanjanje } \\
\text { posljedica } \\
\text { EN* } \\
(3)=(1)+(2)\end{array}$ & $\begin{array}{c}\text { Izdaci iz } \\
\text { proračunske } \\
\text { zalihe (4) }\end{array}$ & $\begin{array}{c}\text { Ukupni izdaci } \\
\text { države (3)+(4) }\end{array}$ \\
\hline 2013. & 19.316 & 19 & 19.335 & - & 19.335 \\
\hline 2014. & 39.132 & 15 & 39.147 & - & 39.147 \\
\hline 2015. & 19.376 & 15 & 19.391 & 10.174 & 29.565 \\
\hline 2016. & 20.000 & 6 & 20.006 & - & 20.006 \\
\hline 2017. & 99.513 & 24 & 99.537 & 7.600 & 107.137 \\
\hline 2018. & 20.000 & 72 & 20.072 & - & 20.072 \\
\hline
\end{tabular}

* EN - elementarne nepogode

Izvor: izrada autora prema podacima Ministarstva financija i Vlade RH.

Osiguranje od posljedica prirodnih nepogoda u Hrvatskoj je slabo zastupljeno jer društvo nije dovoljno informirano i potaknuto na preuzimanje individualne odgovornosti. Prema podacima Hrvatskog ureda za osiguranje, u strukturi ukupno zaračunate bruto premije u Republici Hrvatskoj za 2016., osiguranje od požara i elementarnih šteta sudjeluje sa $6,6 \%$, dok u strukturi likvidiranih šteta osiguranje od požara i elementarnih šteta iznosi $4,1 \%$ (Hrvatski ured za osiguranje [HUO], 2017.). U zemljama Europskog gospodarskog prostora je u razdoblju od 1980. do 2017. osigurano tek oko $35 \%$ ukupnih gubitaka od 
prirodnih nepogoda, a udio osiguranih gubitaka po zemljama se kreće od $1 \%$ u Litvi i Rumunjskoj do $70 \%$ u Ujedinjenom Kraljevstvu. Hrvatska se, udjelom osiguranih gubitaka za to razdoblje od svega $2 \%$, nalazi na samom začelju (European Environment Agency, 2019.). Veća zastupljenost osiguranja smanjila bi utjecaj prirodnih nepogoda na BDP i pritisak na državu u oporavku i saniranju šteta zbog čega je nužno potaknuti stanovništvo na intenzivnije korištenje polica osiguranja.

Od međunarodnih izvora sredstava i pomoći treba istaknuti Fond solidarnosti Europske unije (engl. European Union Solidarity Fund - EUSF) koji je osnovan kako bi se njegovim sredstvima odgovorilo na prirodne nepogode velikih razmjera te izrazila solidarnost među regijama EU-a. Sredstva iz Fonda su se od 2002. koristila za 56 različitih prirodnih nepogoda uključujući poplave, šumske požare, potrese, oluje i suše. Hrvatska je u tom razdoblju primila pomoći od 22,79 mil. eura odnosno 169,03 mil. kuna (Europska komisija, 2018.).

Osim spomenutih izvora sredstava, Ministarstvo poljoprivrede je u sklopu Programa ruralnog razvoja RH za razdoblje 2014. - 2020. operaciju 5.2.1 Obnova poljoprivrednog zemljišta i proizvodnog potencijala, namijenilo saniranju šteta i obnovi poljoprivrednog zemljišta i proizvodnog potencijala narušenog elementarnim nepogodama, nepovoljnim klimatskim prilikama i katastrofalnim događajima (Ministarstvo poljoprivrede, 2018.).

Iako postoji više različitih rješenja i izvora sredstava za sanaciju štete nastale uslijed prirodnih nepogoda, dostupni iznosi tih sredstava su vrlo mali i najčešce ne pokrivaju čak ni dokumentaciju potrebnu za prijavu štete. Iako se od središnje države očekuje najveći financijski angažman, planirana sredstva su nedostatna za podmirenje prijavljenih šteta pa čak i onih potvrđenih. Većina jedinica lokalne samouprave također se oslanja na državni proračun jer nije u mogućnosti sama izdvajati sredstva za sanaciju šteta nastalih uslijed prirodnih nepogoda. Ministarstvo poljoprivrede pruža mogućnost saniranja šteta za poljoprivredna zemljišta, koja su de facto u najvećoj mjeri i izložena negativnim posljedicama prirodnih nepogoda, ali samo uz precizne uvjete koje oštećeni moraju ispuniti. Najveći problem predstavlja slaba zastupljenost osiguranja i nedovoljno preuzimanje rizika od strane samih vlasnika ugrožene imovine, što loše utječe na javne financije i izloženost fiskalnim rizicima.

\section{DOBRE PRAKSE U UPRAVLJANJU FISKALNIM RIZICIMA PRIRODNIH NEPOGODA}

Upravljanje rizicima prirodnih nepogoda neizostavan je dio šireg sustava upravljanja fiskalnim rizicima. Veća otpornost javnih financija na prirodne nepogode postiže se kroz nekoliko ključnih koraka koji obuhvaćaju: procjenu potencijalnih troškova prirodnih nepogoda, poboljšanje sposobnosti financiranja troškova sanacije šteta nastalih uslijed prirodnih nepogoda i smanjenje financijske izloženosti države riziku prirodnih nepogoda (Ghesquiere i Mahul, 2012., str. 2).

Razumijevanje uzroka i posljedica nastanka prirodnih nepogoda iznimno se razvilo tijekom posljednjih nekoliko desetljeća, što je rezultiralo točnijim prognozama i mogućnošću razvoja sustava rane najave i upozoravanja. Nažalost, postoji tendencija podcjenjivanja rizika od prirodnih nepogoda kada se one ne dogode duži niz godina, što uzrokuje slabiju reakciju u trenutku nastanka nepogode (Ivančan-Picek, 2015., str. 306-308). 
Prvi korak u izgradnji učinkovitog sustava upravljanja fiskalnim rizicima prirodnih nepogoda je analiza i identifikacija rizika i ugroženosti nekog područja kako bi se moglo definirati načine smanjenja i upravljanja tim rizicima. Sukladno Odluci Vlade RH, Državna uprava za zaštitu i spašavanje (danas Ravnateljstvo civilne zaštite MUP-a), uz koordinaciju s nadležnim ministarstvima i tijelima, izradila je Procjenu ugroženosti Republike Hrvatske od prirodnih i tehničko-tehnoloških katastrofa i velikih nesreća te Procjenu rizika od katastrofa za Republiku Hrvatsku. U Nacionalnoj procjeni prvotno je identificirano 28 rizika raspoređenih u 11 skupina pri čemu je za svaki od rizika izrađen scenarij, a posljedice događaja vrednovane su utjecajima na život i zdravlje ljudi, gospodarstvo, društvenu stabilnost te politiku. Spomenutih 11 odabranih rizika su: bolesti bilja, bolesti životinja, ekstremne temperature, epidemije i pandemije, industrijske nesreće, poplave izazvane izlijevanjem kopnenih vodenih tijela, potres, požari otvorenog tipa, snijeg i led, suša i zaslanjivanje kopna (DUZS, 2015., str. 3).

Procjena rizika ugroženosti od prirodnih nepogoda za Republiku Hrvatsku predstavlja dobar uvod u prepoznavanje najznačajnijih rizika. DUZS je za Hrvatsku utvrdio izloženost rizicima prirodnih nepogoda te odredio koji su neprihvatljivi rizici kojima se treba pridati veća pozornost. S obzirom na Registar šteta Ministarstva financija koji prikuplja podatke o prijavljenim i potvrđenim štetama prema vrsti prirodne nepogode, moguće je odrediti koje su nepogode u prošlim godinama izazvale najveće štete. Prema tome, moguća je i procjena potencijalnih obveza prema dostupnim povijesnim podacima.

Registar šteta trebao bi osim direktnih obuhvatiti i indirektne troškove prirodnih nepogoda uzrokovane izostankom ekonomske aktivnosti za vrijeme sanacije šteta (Cevik i Huang, 2018., str. 4). Podaci o ukupnim ekonomskim troškovima kao i strukturi šteta nastalih uslijed prirodnih nepogoda preduvjet su za određivanju primjerene metode financiranja i prijenosa rizika prirodnih nepogoda. Trenutno se najviše sredstava izdvaja iz državnog proračuna i dijeli na jedinice lokalne samouprave te oštećene subjekte. Podaci ukazuju da sredstva izdvojena za sanaciju šteta na razini središnje države nisu dostatna za podmirenje troškova prirodnih nepogoda, a uz to postoje i fiksni troškovi za održavanje i funkcioniranje sustava civilne zaštite. Proračuni jedinica lokalne samouprave također su ograničeni zbog čega rijetko koja zasebno izdvaja sredstva za slučaj prirodnih nepogoda. Veliki problem uzrokuje i slaba uključenost privatnog sektora odnosno sektora osiguranja.

U operativnom smislu, učinkovit način smanjenja izloženosti rizicima je usvajanje strogih pravila i procedura u pogledu odgovornih osoba i provedbe postupaka u slučaju prirodnih nepogoda. Dakle, nužno je utvrditi tko je odgovoran za što, tko koordinira službe i javnost na nacionalnoj, ali i na lokalnoj razini. Ulaganja u prevenciju, zaštitu od poplava, odvodnju, infrastrukturu, opremu za spašavanje i ostale resurse mogu pomoći u smanjenju rizika i povećati pripravnost na potencijalne opasnosti. Poticanje na korištenje osiguranja u privatnom i javnom sektoru može smanjiti obveze države prenoseći rizik na treće osobe, tj. osiguravajuća društva (Ghesquiere i Mahul, 2012., str. 4).

Treba probuditi svijest kroz kampanje i medije kako bi se razvilo privatno tržište osiguranja od prirodnih nepogoda, ali i razmotriti uvođenje obveznog osiguranja za sve subjekte (projekte) subvencionirane iz proračuna. Osim toga, država bi trebala razviti program osiguranja javnih sredstava i dobara, što bi potencijalno potaknulo korištenje osiguranja i u privatnom sektoru i, naposljetku, smanjilo troškove za državu (Signer et al., 2016., str. 25). 
Kombinacija metoda financiranja i prijenosa rizika najpoželjnije je rješenje za smanjenje fiskalnih rizika. Za zemlje s velikim javnim dugom, zaduživanje nije poželjno za prikupljanje sredstava potrebnih za sanaciju šteta prirodnih nepogoda. Suvremeni instrumenti prijenosa rizika omogućavaju likvidnost bez zaduživanja što je učinkovito za manje razvijene zemlje. Razvijaju se sustavi i mehanizmi parametrijskog osiguranja u kojem se na regionalnoj razini grupiraju rizici i povećavaju kapaciteti financiranja kombiniranjem rezervi i fondova većeg broja manjih zemalja kako bi imale brži pristup većim iznosima sredstava, nego što to imaju stvarajući vlastite rezerve i fondove (Forni et al., 2015., str. 74-75).

Za prijenos rizika prirodnih nepogoda na međunarodna tržišta potiče se kupnja reosiguranja i izdavanje obveznica za katastrofe. Razvojem kvalitetnog programa upravljanja rizicima prirodnih nepogoda i uspostavljanjem odgovarajućeg makroekonomskog okvira pruža se mogućnost pristupa inovativnoj kreditnoj liniji (engl. Catastrophe Deferred Drawdown Option - CAT DDO) Svjetske banke koja omogućuje brzi pristup financijskim sredstvima nakon proglašenja prirodne nepogode (Ijjasz-Vasquez i Guzman Escobar, 2017.).

\section{ZAKLJUČAK}

Sve veća učestalost prirodnih nepogoda u svijetu i klimatske promjene, uzrokovale su podizanje svijesti o nužnom upravljanju fiskalnim rizicima prirodnih nepogoda. Za financiranje i prijenos rizika prirodnih nepogoda treba odabrati onu metodu koja najbolje odgovara određenoj zemlji s obzirom na njene mogućnosti i potrebe. Ex post metode odnosno metode koje se koriste nakon nastupa nepovoljnog događaja, koristi većina slabije razvijenih zemalja, pri čemu najviše koriste rebalans proračuna i zaduživanje, a oslanjaju se i na pomoć donatora. Ex ante metode iziskuju bolju pripremljenost, ali omogućavaju lakši i brži odgovor na prirodne nepogode. Suvremeni instrumenti prijenosa rizika poput obveznica za katastrofe i potencijalnih kreditnih linija daju mogućnost brzog prikupljanja sredstava. Tradicionalno osiguranje i dalje se smatra ključnim za smanjenje rizika prirodnih nepogoda i neizostavan je dio strategija upravljanja fiskalnim rizicima prirodnih nepogoda u razvijenim zemljama. Sve više zemalja koristi kombinaciju metoda kako bi smanjile ovisnost o samo jednom izvoru financiranja. Za učinkovito upravljanje ovom vrstom rizika iznimno je važno institucionalno i zakonodavno uređenje kako bi se u slučaju materijalizacije rizika (nastupanja štetnog događaja) moglo efikasno organizirati i koordinirati stanovništvom, nadležnim službama i sredstvima.

Republika Hrvatska, kao i ostatak svijeta, bilježi rast u broju prirodnih nepogoda i sve veće iznose šteta i troškova. Nacionalna procjena rizika katastrofa i ugroženosti utvrdila je kroz povijesne podatke, analizu rizika i izradu scenarija, najopasnije prirodne nepogode koje prijete Hrvatskoj. Takva procjena treba se iskoristiti za izradu strategije upravljanja fiskalnim rizicima kako bi se smanjili iznenadni troškovi i šokovi. Registar šteta u proteklih nekoliko godina bilježi prijavljenu štetu od prirodnih nepogoda u iznosima do čak 4,6 mlrd. kuna, a potvrđenu štetu do 2,5 mlrd. kuna, što ukazuje na iznimno visoke troškove i gubitke. Najveći udio prijavljenih šteta, oko $62 \%$, odnosi se na poljoprivredu, a $31 \%$ na građevinarstvo, što su sektori koji uz turizam i energetski sektor, čine gotovo četvrtinu hrvatskog gospodarstva. Treba napomenuti kako je Hrvatska među zemljama s najvećim 
udjelom prijavljenih gubitaka od prirodnih nepogoda u BDP-u i najmanjim udjelom osiguranih gubitaka u ukupnim gubicima u EU. U razdoblju od 2013. do 2018., prijavljena šteta od prirodnih nepogoda u Hrvatskoj iznosi od 0,12 do čak 1,40 \% BDP-a godišnje.

Sredstva koja se u proračunu izdvajaju za prirodne nepogode nisu dostatna za podmirenje troškova prijavljenih šteta, a duge $i$ iscrpne procedure za prijavu šteta i ispunjavanje zahtjeva za naknade šteta uzrokuju nezadovoljstvo stanovništva koje se ne može umanjiti premalim odštetama. No slaba zastupljenost osiguranja pokazuje kako ni stanovništvo nije preuzelo primjeren dio odgovornosti. Oslanjanje na proračun i međunarodnu pomoć donatora nisu dugoročna rješenja za smanjenje rizika od prirodnih nepogoda. Kvalitetna strategija upravljanja fiskalnim rizicima prirodnih nepogoda stvorila bi mehanizam za upravljanje ovom vrstom rizika i preduvjete za smanjenje pritiska na proračun. U tom slučaju bi se proračunska sredstva mogla usmjeriti i na prevenciju te u kombinaciji s tržištem kapitala, osiguranjem i kreditnim linijama stvoriti suvremeni financijski okvir za smanjenje rizika i pripremu na potencijalne troškove prouzročene prirodnim nepogodama.

\section{LITERATURA}

1. Apodaca, C. (2017). Foreign Aid as Foreign Policy Tool, Oxford Research Encyclopedia of Politics, Oxford University Press USA. Dostupno na: http://politics.oxfordre.com/view/10.1093/acrefore/9780190228637.001.0001/acrefore-9780190228637-e-332?print=pdf.

2. Caravani, A., Kellett, J. (2013). Financing Disaster Risk Reduction: A 20 year story of international aid, GFDRR, Global Facility for Disaster Reduction and Recovery, Overseas Development Institute (ODI). Dostupno na: https://www.odi.org/sites/odi. org.uk/files/odi-assets/publications-opinion-files/8574.pdf.

3. Cavallo, E., Noy, I. (2010). The Economics of Natural Disasters, IDB Working paper series, No. IDB-WP-124, Inter-American Development Bank: Department of Research and Chief Economist. Dostupno na: https://www.preventionweb.net/files/12526_ getdocument.pdf,

4. Cevik, S., Huang, G. (2018). Fiscal policy: How to manage the fiscal costs of natural disasters, Washington, DC: International Monetary Fund, Fiscal Affairs Department. Dostupno na: https://www.imf.org/en/Publications/Fiscal-Affairs-Department-How-To-Notes/Issues/2018/06/11/How-to-Manage-the-Fiscal-Costs-of-Natural-Disasters-45941.

5. Directorate-General for European Civil Protection and Humanitarian Aid Operations (ECHO) (2017). Overview of natural and man-made disaster risks the European Union may face, Commission Staff Working Document, Brussels: European Commission. Dostupno na: http://ec.europa.eu/echo/sites/echo-site/files/swd_2017_176_overview_of_risks_2.pdf.

6. Državna uprava za zaštitu i spašavanje (DUZS) (2013). Procjena ugroženosti Republike Hrvatske od prirodnih i tehničko-tehnoloških katastrofa i velikih nesreća, Zagreb, Republika Hrvatska. Dostupno na: http://stari.duzs.hr/download.aspx?f=dokumenti/ Clanci/PROCJENA_web_20.03.2013.pdf. 
7. Državna uprava za zaštitu i spašavanje (DUZS) (2015). Procjena rizika od katastrofa za Republiku Hrvatsku. Dostupno na: http://stari.duzs.hr/download.aspx?f=dokumenti/Clanci/ProcjenarizikaodkatastrofauRH..pdf.

8. European Environment Agency (EEA) (2019) Economic losses from climate-related extremes in Europe. Dostupno na: https://www.eea.europa.eu/data-and-maps/indicators/direct-losses-from-weather-disasters-3/assessment-2.

9. EM-DAT The International disasters database (2015). Dostupno na: https://www.preventionweb.net/countries/hrv/data/.

10. Europska komisija (2018). EU Solidarity Fund Interventions since 2002, Europska komisija/ Regionalni i urbani razvoj EU-a/Regionalna politika/Financiranje/Fond solidarnosti EU-a. Dostupno na: http://ec.europa.eu/regional_policy/sources/thefunds/ doc/interventions_since_2002.pdf.

11. Financial Protection Forum, Providing Contingent Lines of Credit for Disaster Risk Financing, World Bank Group. Dostupno na: https://financialprotectionforum.org/ third-party/microsite_1/resources/Providing $\% 20$ contingent $\% 20$ lines $\% 20$ of $\% 20 \mathrm{cre}$ dit\%20for\%20disaster\%20risk\%20financing.pdf.

12. Forni, M., Khan, H., Mahul, O., Fox, B., Gunasekera, R., White, E., Shah, S., Tehsin, A. (2015). Fiscal disaster risk assessment options for consideration: Pakistan (English). Washington, DC: World Bank Group. Dostupno na: http://documents.worldbank. org/curated/en/829791468070733917/pdf/944740WP0P13260ter0Risk0Assessment. pdf.

13. Ghesquiere, F., Mahul, O. (2010). Financial protection of the state against natural disasters: a primer, Policy Research working paper, No. WPS 5429, Washington, DC: World Bank. Dostupno na: http://documents.worldbank.org/curated/ en/227011468175734792/Financial-protection-of-the-state-against-natural-disasters-a-primer.

14. Ghesquiere, F., Mahul, O. (2012). Building Financial Resilience against Natural Disasters and Climate Change, Commonwealth Finance Ministers Report 2012, Washington DC: Global Facility for Disaster Reduction and Recovery (GFDRR), The World Bank. Dostupno na: https://www.gfdrr.org/sites/default/files/publication/Building_Financial_Resilience_Against_Natural_Disasters_and_Climate_Change.pdf.

15. Hrvatski ured za osiguranje (2017). Zabrinjavajuće niska stopa osiguranja od požara i elementarnih šteta, HUO: Početna/Objave i događaji. Dostupno na: https://huo.hr/ hrv/objave/93/zabrinjavajuce-niska-stopa-osiguranja-od-pozara-i-elementarnih-steta/591/detalji/.

16. Ijjasz-Vasquez, E., Guzman Escobar, A. (2017). Cat DDOs: More than emergency lending for disaster relief, World Bank Blog. Dostupno na: https://blogs.worldbank. org/taxonomy/term/16900.

17. International standard ISO 3100 (2009). Risk management-Principles and guidelines, Ref. No. ISO 31000:2009(E). Dostupno na: http://ehss.moe.gov.ir/getattachment/ 56171e8f-2942-4cc6-8957-359f14963d7b/ISO-31000.

18. Ivančan-Picek, B. (2015). Zaštita okoliša: Vremenski ekstremi - uzroci i posljedice, Kemija u industriji, 64(5-6). Dostupno na: https://hrcak.srce.hr/138937. 
19. Lusine, L., Aliona, C., Ricardo, V., Jeffrey, M., Amine, M., Murray, P., Paolo, M. (2009). Fiscal Risks: Sources, Disclosure, and Management, Departmental Paper No. 09/01, IMF International Monetary Fund. Dostupno na: https://www.imf.org/external/ pubs/ft/dp/2009/dp0901.pdf.

20. Mahmood, M. (2017). Fiscal policy options: Crowding in or crowding out, The Financial Express. Dostupno na: https://thefinancialexpress.com.bd/views/fiscal-policy-options-crowding-in-or-crowding-out.

21. Martinez, A. I., Ore D. (2016). Ecuador will temporarily increase taxes and sell assets to fund reconstruction after earthquake, Reuters. Dostupno na: https://www.businessinsider.com/ecuador-will-increase-taxes-after-earthquake-2016-4.

22. Ministarstvo financija, Prirodne nepogode, MF: Početna/Koncesije i državne potpore/Prirodnenepogode. Dostupno na: http://www.mfin.hr/hr/prirodne-nepogode

23. Munich RE, NatCatService (2011). Natural catastrophe know-how for risk management and research, Munich RE Group. Dostupno na: https://www.munichre.com/site/ corporate/get/documents_E673778764/mr/assetpool.shared/Documents/0_Corporate_Website/Publications/302-06733_en.pdf.

24. NatCatService, Munich RE. Dostupno na: https://natcatservice.munichre.com/events/1?filter=eyJ5ZWFyRnJvbSI6MjAwMCwieWVhclRvljoyMDE3fQ\%3D\%3D\&type=1.

25. OECD (2012). Methodological framework on disaster risk assessment and risk financing, Mexico: G20. Dostupno na: http://www.oecd.org/gov/risk/G20disasterriskmanagement.pdf.

26. Primorac, M., Župančić, I. (2016). The structure and economic significance of government guarantees in Croatia and the European Union, Financial theory and practice, 40(1), str. 63-83. Dostupno na: http://www.fintp.hr/upload/files/ftp/2016/1/primorac_ zupancic.pdf.

27. Signer, B., L., Bogaerts, V. R., Bijelic, M. (2016). Disaster risk finance country note: Serbia (English), Washington, DC: World Bank Group, str. 25. Dostupno na: http:// documents.worldbank.org/curated/en/830671468184737730/Disaster-risk-finance-country-note-Serbia.

28. Skees J. (2009) Ex Ante Financing for Disaster Risk Management and Adaptation, A Public Policy Perspective, University of Kentucky and Global Ag Risk, Inc. Dostupno na: http://globalagrisk.com/Pubs/2009_GlobalAgRisk_\%20Public_Policy_on_Disasters_nov18.pdf.

29. The World Bank (2012) FONDEN: Mexico's Natural Disaster Fund-A Review, Washington DC: World Bank. Dostupno na: https://openknowledge.worldbank.org/handle/10986/26881.

30. The World Bank (2018) The World Bank Affirms Position as Largest Sovereign Risk Insurance Provider with Multi-Country Earthquake Bond, Press Release, Washington, DC: The World Bank. Dostupno na: https://www.worldbank.org/en/news/press-release/2018/02/07/world-bank-affirms-position-as-largest-sovereign-risk-insurance-provider-with-multi-country-earthquake-bond.

31. United Nations Development Programme (2017) Disaster Risk Insurance, Financing Solutions for Sustainable Development, UNDP: Home/Insurance/Disaster Risk Insu- 
rance. Dostupno na: http://www.undp.org/content/sdfinance/en/home/solutions/disaster-risk-insurance.html.

32. *** Zakon o proračunu (NN 15/15.).

33. *** Zakon o sustavu civilne zaštite (NN 82/15.).

34. *** Zakon o ublažavanju i uklanjanju posljedica prirodnih nepogoda (NN 16/19.).

35. *** Zakon o zaštiti od elementarnih nepogoda (NN 73/97.). 